\title{
Quality of the bicucle transportation service in small and intermediate cities in Colombio
}

\author{
Calidad del servicio de transporte en bicicleta en ciudades pequeñas e \\ intermedias de Colombia
}

Qualidade do serviço de transporte em bicicleta em cidades pequenas
e médias da Colômbia

Fecha de recepción: 4 de junio de 2018

Fecha de aprobación: 19 de agosto de 2018

Eduardo Alfonso Pacheco-García*

Alba Yajaira Sánchez-Delgado**

\section{Abstract}

Nowadays, the bicycle, as a means of mobility, is the most eco-friendly vehicle; however, and despite its many benefits, its use at a global scale is quite low. This study aimed to discover the reasons for the low use of bicycles as means of transportation in Colombian, by formulating a method to analyze the service quality of the Bicycle Transportation System (BTS) in small and intermediate cities of the country. Measurement techniques used in the Social Sciences allowed us to study the perception that the user has of the BTS, to identify the most representative attributes of the system and their respective variables, as well as to qualify and quantify them. Applying the method to a case city allowed elucidating the deficiencies perceived by the BTS users, as well as evaluating variables quantitative and qualitatively to obtain a level of service that measures the user acceptance rate of the BTS. The results derived from this method make possible to manage operational actions that improve efficiency in bicycle mobility, with its corresponding economic, environmental and social benefits, to ultimately improve the quality of life of its users. The method and the recommended techniques can be applied to small and intermediate cities, allowing the necessary adjustments for any other type of city.

Keywords: bicycle transport system; measurement techniques; quality of service; service level; user perception.

\section{Resumen}

Hoy en día, la bicicleta, como medio de transporte, es el vehículo más ecológico, sin embargo, y a pesar de sus muchos beneficios, su uso a escala global es bastante bajo. El presente estudio tuvo como objetivo descubrir las razones del bajo uso de la bicicleta como medio de transporte en Colombia, por medio de un método que permitió analizar la calidad del servicio del Sistema de Transporte de Bicicletas (STB) en ciudades pequeñas e intermedias del país. Las técnicas de medición utilizadas en las ciencias sociales permitieron estudiar la percepción que los usuarios tienen del STB, identificar los atributos más representativos del sistema y sus respectivas variables, al igual que cualificar y cuantificarlas. Igualmente, cuando se aplicó el método en una ciudad caso, este permitió observar las deficiencias percibidas por los usuarios del STB, al igual que evaluar cualitativa y cuantitativamente

* M. Sc. Universidad de Pamplona (Pamplona-Norte de Santander, Colombia). eduardo.pacheco@unipamplona.edu.co. ORCID: 0000-00028712-6970.

** M. Sc. Universidad Cooperativa de Colombia (Neiva-Huila, Colombia). alba.sanchezd@campusucc.edu.co. ORCID: 0000-0002-5925-8239. 
las variables para obtener un nivel de servicio que mide la relación de aceptación del STB por parte del usuario. Los resultados derivados de este método hacen posible gestionar acciones operacionales que mejoren la eficiencia de la movilidad en bicicleta, con sus correspondientes beneficios económicos, ambientales y sociales que, en últimas, mejoran la calidad de vida de los usuarios. Este método y las técnicas sugeridas aquí pueden ser aplicados en ciudades pequeñas e intermedias, haciendo los ajustes necesarios para cada tipo de ciudad.

Palabras clave: calidad del servicio; nivel del servicio; percepción del usuario; sistema de transporte de bicicletas; técnicas de medición.

\section{Resumo}

Hoje em dia, a bicicleta, como meio de transporte, é o veículo mais ecológico, porém, e apesar de seus muitos benefícios, seu uso a escala global é bastante baixo. O presente estudo teve como objetivo descobrir as razões do baixo uso da bicicleta como meio de transporte na Colômbia, por meio de um método que permitiu analisar a qualidade do serviço do Sistema de Transporte de Bicicletas (STB) em cidades pequenas e médias do país. As técnicas de medidas utilizadas nas ciências sociais permitiram estudar a percepção que os usuários têm do STB, identificar os atributos mais representativos do sistema e suas respectivas variáveis, ao igual que qualificar e quantificá-las. Igualmente, quando se aplicou o método em uma cidade caso, este permitiu observar as deficiências percebidas pelos usuários do STB, ao igual que avaliar qualitativa e quantitativamente as variáveis para obter um nível de serviço que mede a relação de aceitação do STB por parte do usuário. Os resultados derivados deste método fazem possível implementar ações operacionais que melhorem a eficiência da mobilidade em bicicleta, com seus correspondentes benefícios econômicos, ambientais e sociais que, em últimas, melhoram a qualidade de vida dos usuários. Este método e as técnicas sugeridas aqui podem ser aplicados em cidades pequenas e médias, fazendo os ajustes necessários para cada tipo de cidade.

Palavras chave: qualidade do serviço; nível do serviço; percepção do usuário; sistema de transporte de bicicletas; técnicas de medição.

\section{Cómo citar este artículo:}

E. A. Pacheco-García, and A. Y. Sánchez-Delgado, "Quality of bicycle transportation service in small and intermediate cities in Colombia," Revista Facultad de Ingenieria, vol. 27 (49), pp. 57-64, Sep. 2018. 


\section{INTRODUCTION}

In Colombia, studies on bicycle transport have received little importance, even though this non-motorized vehicle can be quite necessary and useful for journeys, work, and everyday activities that are not exclusive of sports and leisure activities. This kind of transportation can be very useful since it offers an ecological solution to the excessive worrying pollution, saves space, and reduces a series of problems caused by a sedentary lifestyle [1].

A firm commitment to use bicycles must pursue the integration of bicycles in a coherent and progressive way in all their mobility needs [2]. The key to increasing bicycle use is to provide facilities and exclusive and separate infrastructure along busy roads [3]. The broad riding rights of cyclists should be complemented with bike parking, achieving full integration with public transport, comprehensive education on traffic, training for both cyclists and drivers, and a wide range of promotional events to generate enthusiasm and great public [4]. In contrast, in Colombian cities, traffic is generally conditioned by a set of vicious circles that stimulate the motorization process and reduce the role played by alternative means of non-motorized transport, such as cycling.

The numerous attributes of riding bikes benefit both the user and the environment. Cyclists benefit from the low costs of purchase and maintenance with respect to other type of transportation, at the same time that they save time in traffic jams, improve their health by exercising [5] and have greater contact with the environment. Contrary to what is believed, the accident statistics from the Road Safety Agency [6] show that biking is not such a risky means of transportation. This would suppose an increase in the quality of life when adopting this means as a form of daily transport.

According to the Royal Spanish Academy, quality is a property or set of properties inherent to something that gives it the capacity to satisfy implicit or explicit needs. Furthermore, the quality of a product or service is measured as the perception customers have of the service and its ability to meet their needs [7]. When talking about service quality, it is necessary to go back to Europe and the United States in the nineties [8] where the basic concept of the Quality System guaranteed a level of service efficiency; this meant that the result of quality of service was intended and not something imaginary, but the weakness of this system was that it failed to contemplate service improvement and to define a system to evaluate the client. For many years, quality was a forgotten concept, considering it an attribute hard to measure, however, it is an issue that always affects people's satisfaction and is easily recognized [9].

Measuring service quality is very difficult, despite the important practical implications for transport service providers [10]. It is essential to bear in mind that the consumer's evaluation of the quality of service is subjective, abstract and difficult to measure [11]; consequently, it hinders the adequate development of a practice that both validates the results obtained in the evaluation and allows a correct construction of patterns to improve the product. From the consumers perspective, the most important attributes of the quality of service should be taking into account, since they are constantly perceived by current and potential users, considering that specifying these relevant attributes is complex [12].

The Colombian Technical Standard ISO 9001, on customer satisfaction, states that to ensure quality in any activity, it is necessary to plan, control and improve quality, which must be accompanied by a flexible and consistent strategy that comply with environmental requirements. Therefore, investigating the quality of service offered by the BTS is justified, as well as proposing a method to determine user perception, since it is known that people like to talk about bicycles from their own direct experiences [13]. To achieve this, we 1) investigated the relevant aspects to gain user satisfaction, 2) established a plan to collect sources and data related to the service in question, and 3) determined the method that allows linking the sources to identify the user needs.

Regarding the Colombian environment, studies on the quality of service of the Urban Collective Public Transport (UCPT) [14] have defined a method based on quantitative processes to establish the quality of the service. Therefore, this research is oriented to the need to continue studying quality of service in a sustainable means of transport such as the bicycle.

\section{Methodology}

We used the exploratory methodology of qualitativequantitative cut and applied techniques of social 
sciences, such as direct observation, interviews to focal and individual groups, and surveys to users and non-users of bicycle transport in the city of Rionegro (Antioquia). Based on the literature review about quality of service, we formulated a method to identify the perception of the inhabitants of small and intermediate Colombian cities on the quality offered by bicycle transport, taking into account the most representative attributes and their respective variables. The method is framed in the following four steps:

\section{STEP 1: Insertion in the field to study}

STEP 2: Determination of the attributes of quality of service through information gathering techniques. Interviews to individuals and focal groups

STEP 3: Characterization of the attributes of quality of service through information gathering techniques. Interview and survey.

STEP 4: Determination of quality and level of service.

These techniques to collect primary information put into use the method applied in the social environment. During two working days, at peak and non-peak schedules, we applied the technique of direct observation to all the elements of the BTS (user behavior, safety implements, existing infrastructure, traffic authority behavior and behavior of motorvehicle drivers with respect to the cyclist) in sectors with exclusive routes for bicycles, to determine the causes of the deficiencies in the system. To define and hierarchize the main attributes that affect the quality of service, we interviewed two focal groups of eight people each, both composed of people of heterogeneous characteristics (age, stratum, occupation, gender): the first corresponded to users and the second to nonusers of the BTS. Then, we interviewed individuals, applying two types of formats: one with open questions -How do you use the bicycle transport service?, How could the quality of the bicycle transport service be improved?, Why are there so many accidents that are related to bicycle transport?, How do you think a good bicycle transport service should be?, and What are the factors that affect good service?-; and another with closed questions to rank the relevant attributes that were detected in the first format. For the individual interviews, we used a simple random sampling, in which all the elements have the same probability of being selected. To determine sample size, we used equation (1):
Where,

$$
\begin{aligned}
& \mathrm{n}=\left(\mathrm{Z}^{2} \underline{\alpha 2} \stackrel{2}{*} \mathrm{p}^{*} \mathrm{q}\right) / \mathrm{B}^{2} \\
& 1+\left(\mathrm{pqZ}^{2}{ }_{\alpha / 2} / \mathrm{B}^{2}\right) *(1 / \mathrm{N})(1)
\end{aligned}
$$

$\mathrm{n}=$ Sample size .

$\mathrm{Z} \alpha / 2=$ Compatibility level $(95 \%)$

$\mathrm{p}=0.5$

$\mathrm{q}=1-\mathrm{p}$

$\mathrm{B}=$ error allowed (between 0.05 and 0.2 )

$\mathrm{N}=$ study population

This equation gave us a sample size of 377 people, which were selected through a map of the municipality, taking into account the neighborhoods and sites of public interest. Finally, we completed four surveys per user, to evaluate all the hierarchical attributes (safety, comfort, cost and time) using the same sample size. This instrument defined the qualitative and quantitative qualifications for each attribute and the variables that influence them, by evaluating adecuate or inadequate aspects, and determining the service level scales based on speed attributes, such as travel distance, time and speed.

\section{Discussion AND RESUlts}

\section{A. Deficiencies in the BTS}

The geographical location of Rionegro (Antioquia) has a strong impact on the development of all municipalities in the San Nicolás valley, because its location allows the settlement of a series of activities that energize the area and allow all municipalities to interact with the rest of the country. However, in terms of bicycle transport, we observed deficiencies in all the elements. Regarding the users, there is recklessness, excess baggage, lack of security elements and prohibited maneuvers such as talking on the cell phone while driving. Regarding the cyclist network, there is a section of $1.5 \mathrm{~km}$ long of exclusive bicycle lane, with parallel pedestrian path, which is continuous for most of the route, has adequate amplitude, inadequate lighting, lacks maintenance, so sections of asphalt are in bad shape, and has adequate horizontal signage and scarce vertical signage; in terms of shared routes, none is suitable due to the lack of proper signposting. Only four exclusive parking for bikes exist, which are public and free, particularly in shopping malls and supermarkets; and although there is transit authority, its presence is not permanently. Regarding the behavior of the vehicle driver with respect to the 
cyclist, we observed intolerance and disrespect many cases.

\section{B. Identification of relevant attributes}

As a result of the interviews to both individuals and focal groups, users ranked and weighted as outstanding the following attributes in the BTS: safety (42\%), comfort (22\%), economy (12\%) and speed (11\%).

\section{Service level scales}

Based on the surveys, we conducted a statistical analysis of the results to define three scales to measure service levels, based on travel distance, travel time and travel speed, all related to the speed attribute and presented in tables 1, 2 and 3 .
In tables 1,2 and 3, the column acceptance ratio is the relationship between the upper limit of each service level (85th percentile) and the value of that limit for service level C (regular quality). For a case study, knowing the travel distance that users consider regular (service level C), which is obtained with a precise survey on this aspect, allows determining both the remaining service levels and the quality of the service offered at that time regarding the distance traveled.

Table 1 shows that the value obtained for service level $\mathrm{C}$ is $5 \mathrm{~km}$, which is the recommended distance for a trip in Rionegro and that the value deducted for service level D $(7.8 \mathrm{~km})$ is the acceptable distance. From this value onwards, users contemplate the possibility of using another type of transport or, in the worst case, stop using this route if the current system conditions are not improved.

\section{TABLE 1}

LEVEL OF SERVICE BASED ON THE DISTANCE TRAVELED

\begin{tabular}{|c|c|c|c|}
\hline Service Level & Quality & Distance Traveled (km) & Acceptance Relation \\
\hline A & Excellent & $3.5-5.0$ & 0.65 \\
\hline B & Good & $0.8-3.4$ & 0.44 \\
\hline C & Regular & $5.0-7.7$ & 1.00 \\
\hline D & Bad & $7.8-9.6$ & 1.24 \\
\hline E & Appalling & $>9.6$ & 1.24 \\
\hline
\end{tabular}

In table 2, the acceptable travel time of the bicycle tour is 35 minutes, that is, service level C. It seems favorable to the users to maintain travel time between 5 and 35 minutes.

\section{TABLE 2}

LEVEL OF SERVICE BASED ON TRAVEL TIME

\begin{tabular}{|c|c|c|c|}
\hline Service Level & Quality & Travel time (minutes) & Acceptance Relation \\
\hline A & Excellent & $10-18$ & 0.51 \\
\hline B & Good & $5-9$ & 0.26 \\
\hline C & Regular & $19-35$ & 1.00 \\
\hline D & Bad & $36-60$ & 1.71 \\
\hline E & Appalling & $>60$ & 1.71 \\
\hline
\end{tabular}

In table 3, the acceptable travel speed for service level C is $15 \mathrm{~km} / \mathrm{h}$. 


\section{TABLE 3}

SERVICE LEVEL BASED ON TRAVEL SPEED

\begin{tabular}{|c|c|c|c|}
\hline Service Level & Quality & Travel speed (km/hour) & Acceptance Relation \\
\hline A & Excellent & $15-21$ & 1.40 \\
\hline B & Good & $21-24$ & 1.60 \\
\hline C & Regular & $12.7-15$ & 1.00 \\
\hline D & Bad & $10.5-12.6$ & 0.84 \\
\hline E & Appalling & $7-10.5$ & 0.70 \\
\hline
\end{tabular}

\section{Qualification of service quality of bicycle transport}

In the surveys, the user was asked about the quality of service with respect to each variable of the several elements of the system, this qualification was given both qualitatively and quantitatively.
1) Service quality based on the comfort attribute survey: The users rated different variables that affect comfort, related to the driver's education of the motor vehicle, the education of the user, the control of the traffic authorities, and the influence of distances on the comfort of the trip (Table 4).

\section{TABLE 4}

\begin{tabular}{ccc}
\multicolumn{2}{c}{ QUALIFICATION OF THE VARIABLES FOR THE COMFORT ATTRIBUTE } \\
\hline $\begin{array}{c}\text { Aspect } \\
\text { Regarding the driver }\end{array}$ & Quantitative & Qualitative \\
Respect for the norms & 3.4 & Regular \\
Respect for the cyclist & 3.3 & Regular \\
Regarding the user & & Regular \\
Use of the service & 3.3 & Good \\
Freedom of maneuver & 3.7 & \\
Regarding the authorities & & Regular \\
Control exercised & 3.4 &
\end{tabular}

2) Quality of service qualification based on the speed attribute survey: Users were asked about the origin and destination of their last trip (to establish the average distances) and the qualitative rating assigned to the different times of such trip and the distance (Table 5).

\section{TABLE 5}

QUALIFICATION OF THE VARIABLES CORRESPONDING TO THE ATTRIBUTE SPEED

\begin{tabular}{|c|c|c|}
\hline Variable & Average value & Quantitative \\
\hline Travel distance & $7.7 \mathrm{~km}$ & Regular \\
\hline Travel time & 35 minutes & Regular \\
\hline Travel speed & $15 \mathrm{~km} / \mathrm{h}$ & Regular \\
\hline
\end{tabular}

3) Quality of service based on the security attribute survey: Table 6 shows the results of the corresponding ratings. 


\section{TABLE 6}

QUALIFICATION OF THE VARIABLES FOR THE SECURITY ATTRIBUTE

\begin{tabular}{|c|c|c|}
\hline Elemento & Quantitative & Qualitative \\
\hline \multicolumn{3}{|l|}{ Aspects of the network } \\
\hline Existing infrastructure & 3.5 & Regular \\
\hline Signaling & 3.6 & Good \\
\hline Parking lot & 2.9 & Regular \\
\hline Coverage & 3.2 & Regular \\
\hline Maintenance & 3.8 & Good \\
\hline Security & 3.5 & Regular \\
\hline \multicolumn{3}{|l|}{ Motor vehicle driver } \\
\hline Respect for the cyclist & 3.4 & Regular \\
\hline Respect for the norms & 3.5 & Regular \\
\hline \multicolumn{3}{|l|}{ Transit authority } \\
\hline Spatial coverage & 3.5 & Regular \\
\hline Dedicated time & 3.4 & Regular \\
\hline Corrective measures & 3.5 & Regular \\
\hline Preventive measures & 3.3 & Regular \\
\hline Accidents & 4 & Good \\
\hline Robberies & 3.6 & Good \\
\hline \multicolumn{3}{|l|}{ Security elements } \\
\hline Helmet & 3.6 & Good \\
\hline Vest & 3.3 & Regular \\
\hline Lights and reflective & 3.7 & Good \\
\hline Gloves & 3.1 & Regular \\
\hline Elbow pads and knee pads & 3.4 & Regular \\
\hline Horn & 3.4 & Regular \\
\hline State of the bicycle & 4.4 & Good \\
\hline
\end{tabular}

\section{Conclusions}

In the municipality of Rionegro (Antioquia) there are flaws in the different elements that make up the BTS; however, if the government entities improve management and implement actions that benefit the system, these deficiencies can be corrected and the use of bicycles as a sustainable means of mobility can be greatly encouraged. The influence of the social sciences as an instrument for measuring the quality of service in the BTS is a key element in this research, since by using techniques such as observation, interview (individual/focal groups) and survey, we managed to determine the causes of the low use of bicycles as a means of mobility in Rionegro, with specific details on the quality and service levels.

The weighting and ranking of the main attributes that determine the quality of service in the BTS allowed us to conclude that, in Rionegro, users give great importance to safety in terms of adequate infrastructure for bicycles, which clearly reflects that this is a determining factors to adopt the bicycle as a daily means of transport. Noteworthy, both the qualitative and quantitative qualifications of the elements that directly affect the BTS derive from the attributes of safety, comfort and speed. The cost attribute is important because it translates into money saved when making the trip by bicycle instead of using any 
another mode of transport, but is not as determinant as the other three.

Measuring the quality of service quantitatively in a transport system such as bicycle is a complex task, because some attributes such as safety, comfort and time are subjective; however, thanks to the rating scales, it was possible to give a numerical value to these qualitative variables. The levels of service deducted, based on the acceptance relation, allowed us to give real quantitative values, such as a distance of 5 $\mathrm{km}$ deduced as recommendable to make a comfortable journey in the city. Similarly, the acceptable travel time was between 5 and 35 minutes, and the acceptable travel speed was $15 \mathrm{~km} / \mathrm{h}$. The service level scales related to the attribute speed varied according to the characteristics of each city, and, precisely, it was the facility offered by the formulated method that allowed us to make the pertinent adjustments for other cities.

\section{Contributions from the Authors}

Eduardo Alfonso Pacheco García conducted the collection of primary information and the statistical study. Alba Yajaira Sánchez Delgado analyzed the data and formulated the method.

\section{REFERENCES}

[1] M. Jordi-Sánchez, "Estudio de percepciones sobre la salud en usuarios de la bicicleta como medio de transporte," Salud Colectiva, vol. 13(2), pp. 307320, Jul. 2017. DOI: https://doi.org/10.18294/ sc.2017.1164.

[2] M. Orihuel, "Plan Global para la consolidación de la bicicleta como medio de transporte en la UAM," Grade Thesis, Facultad de Ciencias, Universidad Autónoma de Madrid (UAM), Madrid-España, 2007. Available in: https://studylib.es/doc/8368894/.
[3] J. Pucher, J. Dill, and S. Handy, "Infraestructure, programs and policies to increase bicycling: An international review," Preventive Medicine, vol. 50, pp. S106-S125, Jan. 2010. DOI: https://doi. org/10.1016/j.ypmed.2009.07.028.

[4] J. Pucher, and R. Buehler, "Making cycling irresistible: lessons from the Netherlands, Denmark and Germany," Transport Reviews, vol. 28(4), pp. 495-528, Jul. 2008. DOI: https://doi. org/10.180/1441640701806612.

[5] J. Pucher, and R. Buehler, City Cycling, Ed. MIT Press, 2012.

[6] Observatorio Nacional de Seguridad Vial, Histórico de muertos por accidentes viales años 2012-2017. Available in: https://ansv.gov.co/ observatorio/?op $=$ Contenidos $\& \sec =63$.

[7] E. J. Duque, "Revisión del concepto de calidad del servicio y sus modelos de medición," Innovar, vol. 15(25), pp. 64-80, 2005.

[8] C. Grönross. Service Management and Marketing: Managing the Moment of Truth in Service Competition, USA: Lexington Books, 1990.

[9] L. E. Palacios, Principios esenciales para realizar proyectos: Un enfoque latino, Caracas: Universidad Católica Andrés Bello, Venezuela, 2000.

[10] P. Priony, and D. A. Hesher, "Measuring Service Quality in Scheduled Bus Services", Journal of Public Transportation, vol. 3(2), p. 24, Jan. 2000.

[11] A. Parasuraman, V. A. Zeithaml, and L. L. Berry, "A conceptual model of service quality and its implications for future research," Journal of Marketing, vol. 49 (4), pp.41-50, 1985. DOI: https:// doi.org/10.2307/1251430.

[12] B. Edvardsson, "Causes of customer dissatisfactionstudies of public transport by the critical-incident method", Journal of Service Theory and Practice, vol. 8(3), pp. 189-197, Jun. 1998.

[13] D. Horton, P. Rosen, and P. Cox, Cycling and Society, London and New York: Ed. Routledge Taylor \& Francis Group, 2016.

[14] D. E. Dueñas, "Calidad del Servicio de Transporte Público en Autobuses en ciudades pequeñas e intermedias en el ámbito latinoamericano", Doctoral Thesis, Universidad Politécnica de Valencia, Valencia-España, 2000 